\title{
In vitro cytotoxicity of Aspilia pluriseta Schweinf. extract fractions
}

\author{
Sospeter N. Njeru ${ }^{1,3^{*}}$ and Jackson M. Muema²
}

\begin{abstract}
Objectives: We and others have shown that Aspilia pluriseta is associated with various biological activities. However, there is a lack of information on its cytotoxicity. This has created an information gap about the safety of $A$. pluriseta extracts. As an extension to our recent publication on the antimicrobial activity and the phytochemical characterization of A. pluriseta root extracts, here we report on cytotoxicity of tested solvent fractions. We evaluated the potential cytotoxicity of these root extract fractions on Vero cell lines by 3-(4,5-dimethylthiazol-2-yl)-2,5-diphenyltetrazolium bromide (MTT) assay.

Results: We show that all solvent extract fractions (except methanolic solvent fractions) had cytotoxic concentration values that killed $50 \%$ of the Vero cells $\left(\mathrm{CC}_{50}\right)$ greater than $20 \mu \mathrm{g} / \mathrm{mL}$ and selectivity index (SI) greater than 1.0. Taken together, we demonstrate that, A. pluriseta extract fractions' earlier reported bioactivities are within the acceptable cytotoxicity and selective index limits. This finding scientifically validates the potential use of A. pluriseta in the discovery of safe therapeutics agents.
\end{abstract}

Keywords: Vero cells, Medicinal/herbal plants, Traditional/folk medicine, MTT assay, Selectivity index, Phytochemicals

\section{Introduction}

Plant-derived products and compounds have been used to treat and manage a wide range of diseases and infections since ancient times. The utilization of plant-derived products and compounds is favoured because these products and compounds exhibit fewer side effects, have improved efficacy and have reduced chances of developing resistance [1-5]. The bioactivity of plant extracts are a result of secondary metabolites, also called phytochemicals [3]. These phytochemicals are produced for normal plant defences. However, they inadvertently work against microbial systems and thus are often tapped for therapeutic interventions.

Here we extend the findings of our previous publications [5, 6] by looking at the safety of Aspilia pluriseta Schweinf. (Asteraceae) extract fractions in an in vitro

\footnotetext{
*Correspondence: hicogn@gmail.com

1 Department of Biochemistry, School of Health Sciences, Kisii University, P.O. Box 408-40200, Kisii, Kenya

Full list of author information is available at the end of the article
}

system. A. pluriseta is a common herb in Kenya [5, 7], as well as in East, Central, and Southern Africa, [8, 9]. A. pluriseta is traditionally used to manage and treat wounds, cough, stomach illness, burn wounds, pimples, ears-, eye-, nose infections, kwashiorkor, fever, worms disorders, and diabetes mellitus with little or no scientific validation [7, 9-14]. Recently we have reported A. pluriseta selective antitubercular activity [5]. Other studies have reported A. pluriseta antiviral [9], antihelmintic [15], antimalarial, hypoglycaemic [7, 14, 16], molluscicidal [17] and complement modulating activities [18]. However, the scientific evidence of its pharmacological activity is not fortified by data on its cytotoxicity. We therefore aimed to fill this scientific information-gap using an in vitro cytotoxicity system. We report that, the A. pluriseta extract fractions (except methanol solvent fraction) have $\mathrm{CC}_{50}>20 \mu \mathrm{g} / \mathrm{mL}$, and $\mathrm{SI}>1.0$, which indicates that, $A$. pluriseta extract fractions are safe for use in drug discovery and that the reported bioactivity is not a result general toxicity.

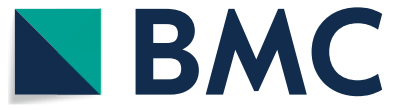

(c) The Author(s) 2021. This article is licensed under a Creative Commons Attribution 4.0 International License, which permits use, sharing, adaptation, distribution and reproduction in any medium or format, as long as you give appropriate credit to the original author(s) and the source, provide a link to the Creative Commons licence, and indicate if changes were made. The images or other third party material in this article are included in the article's Creative Commons licence, unless indicated otherwise in a credit line to the material. If material is not included in the article's Creative Commons licence and your intended use is not permitted by statutory regulation or exceeds the permitted use, you will need to obtain permission directly from the copyright holder. To view a copy of this licence, visit http://creativeco mmons.org/licenses/by/4.0/. The Creative Commons Public Domain Dedication waiver (http://creativecommons.org/publicdomain/ zero/1.0/) applies to the data made available in this article, unless otherwise stated in a credit line to the data. 


\section{Main text \\ Methodology \\ Plant material collection}

Ethnopharmacological approach was used to identify the plant under study (A. pluriseta). This involved collecting information on $A$. pluriseta herbal use in the management and treatment of "strong coughs" and complicated respiratory infections from Mbeere community herbal practitioners. The gleaned information was further confirmed from documentation by Riley and Brokensha (1988) in The Mbeere in Kenya (ii), Botanical identity and use [19]. A. pluriseta root samples were collected in an open community field, and the plant is not among the endangered plant species. Therefore, no prior permission was sought before the plant samples were collected. We collected the plant samples within GPS co-ordinates $0^{\circ} 46^{\prime} 27.0^{\prime \prime} \mathrm{S} 37^{\circ} 40^{\prime} 54.9^{\prime \prime} \mathrm{E}$; -0.774156, 37.681908. Further authentication of plant sample identity was undertaken by Prof. S. T. Kariuki, a botanist at Egerton University, Kenya. A voucher specimen (number NSN2) was assigned and deposited at the same institution's herbalium.

\section{Processing of plant samples}

The plant materials were processed, extracted and finally fractionated as described in Njeru and Muema [5]. Briefly, root materials were cut into small pieces and allowed to air-dry in the dark at $23 \pm 2{ }^{\circ} \mathrm{C}$ until they attained a constant weight. They were thereafter ground into fine powder with an electric miller (Retsch SR 200, Haan, Germany). Fifty grams of ground material was macerated in $200 \mathrm{~mL}$ methanol (Sigma Aldrich, St. Louis, USA) for $48 \mathrm{~h}$. The extract was filtered out using Whatmann 1 filter paper, and the process repeated once more. Both filtrates were pooled together, and excess methanol evaporated from the filtrate by a rotor evaporator (Laborota 4000 efficient, Heidolph, Germany). The resulting dry extract was stored at $-20^{\circ} \mathrm{C}$ until use. To fractionate A. pluriseta root samples, we used organic solvents of increasing polarity (petro ether, dichloromethane, ethyl acetate and methanol respectively). Root powder (50 g) was macerated in $200 \mathrm{~mL}$ of petro ether solvent with intermittent shaking for $48 \mathrm{~h}$. Thereafter, the extract was filtered out. Another $200 \mathrm{~mL}$ petro ether (PE) was added into plant material, and the process repeated after which the two filtrates were pooled together. The resulting marc was air-dried, after which it was further fractionated with solvents of increasing polarity (namely dichloromethane (DCM), ethyl acetate (EA), and finally methanol $(\mathrm{MeOH})$ solvent in that order. The organic solvent fractions were concentrated with rotor evaporator as described before [5]. For assays, the organic solvent fractions were reconstituted into appropriate stock solutions with 100\% dimethyl sulfoxide (DMSO), but diluted appropriately with culture medium so that the final DMSO concentration in the test sample was one percent, and therefore $1 \%$ DMSO was used as the negative control. The antitubercular activity, general antimicrobial activity, as well as the analytical characterization of phytochemicals of crude extract and solvent extract fractions evaluated here have been reported in our previous publications $[5,6]$.

\section{In vitro cytotoxicity test}

An MTT assay previously described by Njeru, Obonyo [20] was followed to evaluate the toxicity of the A. pluriseta extract fractions on Vero cells (from African green monkey kidney cells (Cercopithecus aethiops epithelial cell line; ATCC CCL-81)). MTT assay is a colourimetric assay pegged on the ability of mitochondrial enzyme (succinate dehydrogenase) to reduce tetrazolium salt MTT to water-insoluble coloured substance (formazan) that is spectrophotometrically measurable [21, 22]. The amount of the formazan formed is directly proportional to the measure of cell viability. This is because only metabolically active cells can reduce MTT into formazan. The Vero cell line grown to $70-80 \%$ confluency in a medium (containing $100 \mathrm{~mL}$ DMEM, $10 \mathrm{~mL}$ fetal bovine serum (FBS), $1 \mathrm{~mL}$ penicillin-streptomycin, $1 \mathrm{~mL}$ amphotericin $\mathrm{B}, 1 \mathrm{~mL}$ L-glutamine and $0.1 \mathrm{~mL}$ gentamycin) was incubated in the presence of sample extract fractions at standard conditions $\left(37{ }^{\circ} \mathrm{C}\right.$ in $\left.5 \% \mathrm{CO}_{2}\right)$ at $1.0 \times 10^{5}$ cells/ $\mathrm{mL}$ in a 96-well microtiter plate. The cells were exposed to decreasing concentrations of respective solvent extract fractions $(250-0.24 \mu \mathrm{g} / \mathrm{mL}$ for petroleum ether and dichloromethane fractions; $500-0.49 \mu \mathrm{g} / \mathrm{mL}$ for ethyl acetate and methanolic fraction). Each sample concentration was tested in duplicates for $48 \mathrm{~h}$. A post-exposure incubation of $4 \mathrm{~h}$ in $10 \mu \mathrm{L}$ of $5 \mathrm{mg} / \mathrm{mL}$ MTT solution followed the addition of $100 \mu \mathrm{L}$ acidified isopropanol (0.04 $\mathrm{N} \mathrm{HCl}$ in isopropanol). The well plates were gently shaken for $5 \mathrm{~min}$ to dissolve the formazan in acidified isopropanol, and then optical density measured using ELISA Scanning Multiwell Spectrophotometer (LabSystems-Multiskan EX) at $562 \mathrm{~nm}$ using $690 \mathrm{~nm}$ as the reference wavelengths. The last column of microtiter well plate containing medium without plant solvent extract fractions, but with $1 \%$ DMSO, was included as the negative control. The percentage cell viability (\%) was calculated at each concentration using the formula provided below $[1,20,23]$.

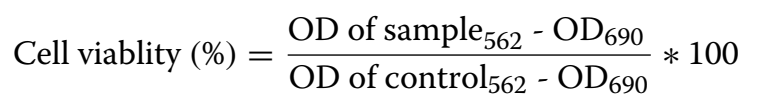

Cytotoxic concentration values which represented the treatment concentration that kills $50 \%$ of the Vero cells 
Table 1 Cytotoxicity of $A$. pluriseta solvent crude and fraction extracts

\begin{tabular}{llllll}
\hline & cMeOH & PE & DCM & EA & MeOH \\
\hline $\mathrm{CC}_{50}(\mu \mathrm{g} / \mathrm{mL})$ & 24.51 & 78.6 & 191.7 & $>500$ & 14.36
\end{tabular}

$\mathrm{CMeOH}, \mathrm{Crude}$ methanolic extract; $\mathrm{PE}$, Petroleum ether solvent fraction; DCM, Dichloromethane solvent fraction; EA, Ethyl acetate solvent fraction; $\mathrm{MeOH}$, Methanol solvent fraction; $\mathrm{CC}_{50}$, Concentration that kills $50 \%$ of the cells

Table 2 Selectivity index of $A$. pluriseta solvent extract fractions

\begin{tabular}{lllll}
\hline & PE & DCM & EA & MeOH \\
\hline Selectivity index & 3.144 & 7.668 & 80 & 1.1488 \\
\hline
\end{tabular}

$\mathrm{PE}$, Petroleum ether solvent fraction; DCM, Dichloromethane solvent fraction; $\mathrm{EA}$, Ethyl acetate solvent fraction; $\mathrm{MeOH}$, Methanol solvent fraction

$\left(\mathrm{CC}_{50}\right)$, was determined by regression analysis. A particular plant solvent extract fraction was considered cytotoxic if it had $\mathrm{CC}_{50}$ of less than $20 \mu \mathrm{g} / \mathrm{mL}$ and selectivity index (SI) of less than $1.0[1,24,25]$.

\section{Results}

The cytotoxicity test was performed against Vero cells (from monkey kidney fibroblast cells) to ascertain the safety of $A$. pluriseta solvent extract fractions. We chose the Vero cell line as an ideal in vitro model for the study because of its sensitivity to toxicity, ease to culture, and it was readily available in our test facility. Additionally, Vero cells are recommended as a model to detect basal cytotoxicity $[1,26,27]$. In this study, we set a threshold of the cytotoxic concentration $\left(\mathrm{CC}_{50}\right)$ below $20 \mu \mathrm{g} / \mathrm{mL}$ to be toxic, and above $20 \mu \mathrm{g} / \mathrm{mL}$ to be non-toxic as previously reported [1, 24, 25]. Our initial test for the cytotoxicity of the methanolic crude $(\mathrm{cMeOH})$ extract revealed that the $\mathrm{CC}_{50}$ was within the acceptable toxicity limit $\left(\mathrm{CC}_{50}\right.$ of 24.51) [6]. Therefore, we hypothesized that fractionation could help us identify active fractions that would not only maintain a strong bioactivity [5] but also be within the acceptable toxicity limits $\left(\mathrm{CC}_{50}>20 \mu \mathrm{g} / \mathrm{ml}\right)$, and selectivity limits $(\mathrm{SI}>1.0)$. Solvent extract fractionation gave us one fraction $\left(\mathrm{MeOH}\right.$ at $\left.\mathrm{CC}_{50} 14.36 \mu \mathrm{g} / \mathrm{ml}\right)$, which was cytotoxic. The PE fraction at $\mathrm{CC}_{50} 78.6 \mu \mathrm{g} / \mathrm{ml}$, DCM fraction, at $\mathrm{CC}_{50}$ of $191.7 \mu \mathrm{g} / \mathrm{ml}$, and EA fraction at $\mathrm{CC}_{50}>500 \mu \mathrm{g} / \mathrm{ml}$ were all within the acceptable toxicity limit according to the set criteria (Table 1 ).

To determine the selectivity index (SI) of the solvent extract fractions, we divided their $\mathrm{CC}_{50}$ with their antitubercular MIC (all in $\mu \mathrm{g} / \mathrm{mL}$ ) (data published in [5]) as previously done by others $[1,24,25]$. The SI ranged from 1.1488 to 80 (Table 2), which according to Afagnigni, Nyegue [1] and Mongalo, McGaw [24], suggested that the $A$. pluriseta extract fractions were not toxic, or, in the case of $\mathrm{MeOH}$ solvent extract fraction, that it exhibited cytotoxicity and antitubercular activity almost equally [1, $24,25]$.

\section{Discussion}

Although plants' contribution to new and novel leads for therapeutic drug development has been accepted for a long time now, it is currently a known fact that plant extracts are not always safe [20, 28]. The cytotoxicity of many herbal-derived products is a potential source of more deleterious side effects to subjects. It is, therefore, imperative to determine whether plant extracts and products showing potential drug activities are active within the acceptable toxicity and selectivity index limits $[1,24,25,29,30]$. Interestingly, we found that the crude extract and solvent extract fractions (except methanolic solvent extract fraction) demonstrated activity within the acceptable cytotoxicity limit (Table 1). Furthermore, all the solvent fractions had selectivity index of $>1.0$, which further confirms that the solvent extract fractions are not toxic and hence the reported bioactivity in [5] was not due to basal metabolic toxicity, or in the case of $\mathrm{MeOH}$ solvent extract fraction, the bioactivity and cytotoxicity are almost the same [24].

\section{Conclusion}

Our findings demonstrate that $A$. pluriseta root solvent extract fractions' previously reported bioactivity is within acceptable cytotoxicity and selectivity index limit, and thus provide a potential source for safe drug candidate(s).

\section{Limitation}

It is important to note that the in vitro cytotoxicity results do not always equate to in vivo toxicity. This may be attributed to physiological, anatomical pharmacodynamic, and pharmacokinetic considerations in living animals and cell culture [1, 24, 29]. Therefore, there is a need for further in vivo toxicity assessment of the extract fractions. In this study, we evaluated the cytotoxicity of solvent extract fractions. However, it will be interesting in the future to isolate the active phytoconstituents (which we previously reported to be present in the tested extracts $[5,6])$ and test their individual biological and cytotoxicity effects.

\section{Abbreviations}

PE: Petroleum ether; DCM: Dichloromethane; EA: Ethyl acetate; MeOH: Methanol; $\mathrm{CMeOH}$ : Crude methanolic extract; MTT: 3-(4,5-Dimethylthiazol-2-yl)-

2,5-diphenyltetrazolium bromide; $\mathrm{CC}_{50}$ : Cytotoxic concentration values that killed $50 \%$ of the Vero cells; SI: Selective index. 


\section{Acknowledgements}

The authors would wish to acknowledge KEMRI- especially Dr. Bii C., among others, Kisii University (Prof. Anakalo S.) and Egerton University, (Prof. Matasyoh J.C., Prof. Ngari S.M., Dr. Obonyo A.M, and Mr. Nyambati S.O.) for the support they gave to the work.

\section{Authors' contributions}

SNN conceived the idea, sought, and was awarded the funding and worked through the final draft. JMM partly performed the experimental studies, wrote the initial draft. Both authors read and approved the final manuscript.

\section{Funding}

This study was supported by the International Foundation for Science, Stockholm, Sweden, through IFS Grant No. F/5372-1 to Dr. Sospeter Ngoci, Njeru. The funding body did not participate in the design of the study and collection, analysis, and interpretation of data and in the writing of the manuscript.

\section{Availability of data and materials}

All data generated or analyzed during this study are included in this published article.

\section{Ethics approval and consent to participate \\ Not applicable.}

\section{Consent for publication}

Not applicable.

\section{Competing interests}

The authors declare that they have no competing interests.

\begin{abstract}
Author details
${ }^{1}$ Department of Biochemistry, School of Health Sciences, Kisii University, P.O. Box 408-40200, Kisii, Kenya. ${ }^{2}$ Department of Biochemistry, Jomo Kenyatta University of Agriculture and Technology (JKUAT), P.O. Box 62000-00200, Nairobi, Kenya. ${ }^{3}$ Present Address: Division of Immunology, Paul-Ehrlich-Institute, Federal Institute for Vaccines and Biomedicines, Paul-Ehrlich-Straße 51-59, 63225 Langen, Hessen, Germany.
\end{abstract}

Received: 17 October 2020 Accepted: 1 February 2021 Published online: 09 February 2021

\section{References}

1. Afagnigni AD, Nyegue MA, Djova SV, Etoa F-X. LC-MS analysis, 15-lipoxygenase inhibition, cytotoxicity, and genotoxicity of dissotis multiflora (Sm) triana (melastomataceae) and Paullinia pinnata Linn (Sapindaceae). J Trop Med. 2020;2020:5169847.

2. Mir MA, Bashir N, Alfaify A, Oteef MDY. GC-MS analysis of Myrtus communis extract and its antibacterial activity against Gram-positive bacteria. BMC Complement Med Therapies. 2020;20(1):86.

3. Kuete V. Potential of Cameroonian plants and derived products against microbial infections: a review. Planta Med. 2010;76(14):1479-91.

4. Batiha GE, Beshbishy AM, Alkazmi L, Adeyemi OS, Nadwa E, Rashwan E, et al. Gas chromatography-mass spectrometry analysis, phytochemical screening and antiprotozoal effects of the methanolic Viola tricolor and acetonic Laurus nobilis extracts. BMC Complement Med Therapies. 2020;20(1):87.

5. Njeru SN, Muema JM. Antimicrobial activity, phytochemical characterization and gas chromatography-mass spectrometry analysis of Aspilia pluriseta Schweinf. extracts. Heliyon. 2020;6(10):e05195.

6. Njeru SN, Obonyo MA. Potency of extracts of selected plant species from Mbeere, Embu County-Kenya against Mycobacterium tuberculosis. J Med Plants Res. 2016;10(12):149-57.

7. Yaouba S, Valkonen A, Coghi P, Gao J, Guantai EM, Derese S, et al. Crystal structures and cytotoxicity of ent-kaurane-type diterpenoids from two Aspilia species. Molecules. 2018;23(12):1-13.

8. Gachathi FN. Kikuyu botanical dictionary: a guide to plant names, uses and cultural values. Trop Botany. 2007.

9. Cos P, Hermans N, De Bruyne T, Apers S, Sindambiwe JB, Witvrouw M, et al. Antiviral activity of Rwandan medicinal plants against human immunodeficiency virus type-1 (HIV-1). Phytomedicine. 2002;9(1):62-8.
10. Njoroge GN, Bussmann RW. Traditional management of ear, nose and throat (ENT) diseases in Central Kenya. J Ethnobiol Ethnomed. 2006;2(1):1.

11. Njoroge GN, Bussmann RW. Ethnotherapeautic management of skin diseases among the Kikuyus of Central Kenya. J Ethnopharmacol. 2007;111(2):303-7.

12. Piero NM, Joan MN, Cromwell KM, Joseph NJ, Wilson NM, Daniel M, et al. Hypoglycemic activity of some kenyan plants traditionally used to manage diabetes mellitus in Eastern Province. J Diabetes Metabol. 2011. https://doi. org/10.4172/2155-6156.1000155.

13. Kuria JM, Mbaria JM, Gathumbi PK, Kiama SG. Influence of Aspilia pluriseta Schweinf (Asteraceae) on the healing of dermal excision wounds (mouse model) and skin sensitization activity (Guinea pig model). Afr J Pharmacol Ther. 2015;4(3):112-7.

14. Sebisubi FM, Odyek O, Anokbonggo WW, Ogwal-Okeng J, Carcache-Blanco EJ, Ma C, et al. Antimalarial activity of Aspilia pruliseta, a medicinal plant from Uganda. Planta Med. 2010;76(16):1870-3.

15. Njonge FK, Mutugi M, Kareru PG, Githigia SM, Waihenya R, Nyakundi WO. Assessment of herbal anthelmintics used by the farmers in Kirinyaga County, Kenya, for the treatment of helminthiosis in cattle. Afr J Pharm Pharmacol. 2013;7(29):2100-4.

16. Munster WB, Dusseldorf RB, Franz G, Zurich OS, HerzW, Zurich MH, et al. Antimycobacterial plant terpenoids. Planta Med. 2001;67:685-94.

17. Mwonga KB, Mwaniki E, Dorcas YS, Piero NM. Molluscicidal effects of aqueous extracts of selected medicinal plants. Pharmaceutica Analytica Acta. 2015. https://doi.org/10.4172/2153-2435.1000445.

18. Cos P, Hermans N, Van Poel B, De Bruyne T, Apers S, Sindambiwe JB, et al. Complement modulating activity of Rwandan medicinal plants. Phytomedicine. 2002;9(1):56-61.

19. Riley BW, Brokensha D. The Mbeere in Kenya; Botanical identity and use Vol (ii). USA: University Press of America; 1988.

20. Njeru SN, Obonyo MA, Nyambati SO, Ngari SM. Antimicrobial and cytotoxicity properties of the crude extracts and fractions of Premna resinosa (Hochst.) Schauer (Compositae): Kenyan traditional medicinal plant. BMC Complement Alternative Med. 2015;15:295.

21. Rai Y, Pathak R, Kumari N, Sah DK, Pandey S, Kalra N, et al. Mitochondrial biogenesis and metabolic hyperactivation limits the application of MTT assay in the estimation of radiation induced growth inhibition. Sci Rep. 2018;8(1):1531.

22. Mosmann T. Rapid colorimetric assay for cellular growth and survival: application to proliferation and cytotoxicity assays. J Immunol Methods. 1983;65(1):55-63.

23. Zulaikha N, Zawawi M, Shaari R, Nordin ML, Hamdan RH, Peng TL, et al. Antibacterial and cytotoxic activity assessment of Channa striatus (Haruan) extract. Veterinary World. 2020;13:508-14.

24. Mongalo NI, McGaw $\perp$, Finnie JF, Staden JV. Pharmacological properties of extracts from six South African medicinal plants used to treat sexually transmitted infections ( STIs ) and related infections. South Afr J Botany. 2017;112:290-5.

25. Zirihi GN, Mambu L, Bodo B, Grellier P. In vitro antiplasmodial activity and cytotoxicity of 33 West African plants used for treatment of malaria. J Ethnopharmacol. 2005;98(3):281-5.

26. Omokhua AG, Abdalla MA, Staden JV, McGaw L. A comprehensive study of the potential phytomedicinal use and toxicity of invasive Tithonia species in South Africa. BMC Complement Alternative Med. 2018;18:1-15.

27. Freire PF, Peropadre A, Martín JMP, Herrero O, Hazen MJ. Toxicology in vitro an integrated cellular model to evaluate cytotoxic effects in mammalian cell lines. Toxicol In Vitro. 2009;23(8):1553-8.

28. Vijayarathna S, Sasidharan S. Cytotoxicity of methanol extracts of Elaeis guineensis on MCF-7 and Vero cell lines. Asian Pac JTrop Biomed. 2012;2(10):826-9.

29. Makhafola TJ, McGaw $\sqcup$, Eloff JN. In vitro cytotoxicity and genotoxicity of five Ochna species (Ochnaceae) with excellent antibacterial activity. South Afr J Botany. 2014;91:9-13.

30. Stefanović O, Radojević I, Vasić S, Čomić L. Antibacterial activity of naturally occurring compounds from selected plants. American Phytopathol Soc. 2005:1-24.

\section{Publisher's Note}

Springer Nature remains neutral with regard to jurisdictional claims in published maps and institutional affiliations. 